\title{
Corynebacterium maris sp. nov., a marine bacterium isolated from the mucus of the coral Fungia granulosa
}

\author{
Eitan Ben-Dov, ${ }^{1,2}$ Dafna Zeevi Ben Yosef, ${ }^{1}$ Valentina Pavlov ${ }^{1}$ \\ and Ariel Kushmaro ${ }^{1}$
}

Correspondence

Ariel Kushmaro

arielkus@bgu.ac.il

\author{
${ }^{1}$ Department of Biotechnology Engineering, and National Institute for Biotechnology, Ben-Gurion \\ University of the Negev, PO Box 653, Be'er-Sheva 84105, Israel \\ ${ }^{2}$ Achva Academic College, MP Shikmim 79800, Israel
}

The genus Corynebacterium (phylum Actinobacteria) was originally described in 1896 as a primarily pathogenic species that showed morphological similarity to the diphtheroid bacillus (Barksdale, 1970; Ventura et al., 2007). The genus Corynebacterium includes both aerobic and facultatively anaerobic, asporogenous Gram-positive species (Collins \& Cummins, 1986). Some species synthesize tuberculostearic acid and/or short-chain and structurally distinctive mycolic acids (Collins et al., 1982), while some lack mycolic acids (Collins et al., 1988, 2004). Consequently, for several decades, the genus comprised an extremely diverse collection of morphologically similar Gram-positive micro-organisms, including pathogenic and non-pathogenic soil bacteria (Collins \& Cummins, 1986). Chemotaxonomic studies and comparative phylogenetic analyses have defined the border of the genus Corynebacterium, clearly demonstrating that species assigned to this genus form a monophyletic association and, together with other chemotype IV and mycolic acidcontaining taxa (including the genera Dietzia, Gordonia, Millisia, Mycobacterium, Nocardia, Rhodococcus, Segniliparus, Skermania, Tsukamurella and Williamsia),

The GenBank/EMBL/DDBJ accession number for the 16S rRNA gene sequence of strain Coryn $-1^{\top}$ is FJ423600.

An extended phylogenetic tree based on 16S rRNA gene sequences is available as supplementary material with the online version of this paper. form a natural suprageneric group (Pascual et al., 1995; Ruimy et al., 1995). Corynebacterium strains exhibit considerable heterogeneity in mycolic acid content as well as in DNA G $+\mathrm{C}$ content, which ranges from 46 to 74 mol\% (Ruimy et al., 1995). Currently, there are over 90 recognized species of the genus Corynebacterium (Euzéby, 2007), including many novel species isolated from human clinical samples (Otsuka et al., 2005; Riegel et al., 2006; Renaud et al., 2007), wild animals (Collins et al., 2004; Fernández-Garayzabal et al., 2004; Goyache et al., 2003), saline soil (Chen et al., 2004), food (Brennan et al., 2001) and even from cosmetic dye (Yassin et al., 2003).

Scleractinian corals make up the backbone of coral reefs and are the most diverse of all marine ecosystems. These corals harbour large, diverse and specific populations of micro-organisms, including viruses, bacteria, archaea, algae, fungi and protozoa that have apparently co-evolved with them (Rosenberg et al., 2007). Studies have revealed a dynamic microbial biota living in the mucus, on the surface and in the tissues of many coral species but still little is known of their function, metabolic capabilities and their potential benefit to the coral host. Recently, the development of high-throughput culturing techniques and the application of single-cell isolation methods have improved the isolation of micro-organisms from their natural habitats (Giovannoni et al., 2007). In the present 
study, we used phenotypic, chemical and genetic methodologies to facilitate the characterization of a Corynebacteriumlike organism recovered from mucus of the coral Fungia granulosa from the Red Sea.

Samples of mucus from healthy corals of $F$. granulosa were collected from the Red Sea (Gulf of Eilat) from depths of $10-15 \mathrm{~m}$, in front of the Inter-University Institute for Marine Science, Eilat, Israel $\left(29^{\circ} 51^{\prime} \mathrm{N} 34^{\circ} 94^{\prime}\right.$ E). Sterile bacteriological quadloops were carried into these waters to collect the coral surface microlayer in situ. Near the coral, a sterile $15 \mathrm{ml}$ polypropylene tube was opened upside down and mucus was collected from the coral surface using quadloops (three in every tube). Before sealing and while the tube was still in an upside-down position, compressed air was added and the vial was sealed to exclude seawater. The tubes were brought to the surface and immediately placed on ice. An initial culture of strain Coryn $-1^{\mathrm{T}}$ was isolated through the use of a recently developed agarsphere culturing technique (patent applications WO 2004/ 022698 A2 and EP1556480). This encapsulation technology for isolating and culturing previously uncultivable microorganisms includes collecting an environmental sample, estimating the bacterial number and diluting the sample in order to entrap approximately one bacterium per agar sphere. Dripping the diluted samples mixed with warm autoclaved agar into cold mineral oil leads to the formation of spheres, the size of which (1-2 $\mathrm{mm}$ in diameter) can be modulated by the nozzle diameter and drip rate. The agar spheres are coated with a polymeric membrane by inserting the spheres into a polymer solution (polysulfone) and transferring them to a polymerization medium. The polymeric membrane allows the exchange of chemicals between the sphere and the environment but restricts the movement of cells, thus enabling bacterial incubation in environmental conditions. Enrichment of strain Coryn- $1^{\mathrm{T}}$ was achieved by repeated transfer through agar spheres incubated in proximity to the coral and subsequent plating on $100 \%$ marine agar 2216 (MA-100\%; HiMedia Laboratories) plates. Liquid Luria-Bertani (LB) or marine broth cultures of the strain were spread onto LB or MA$100 \%$ plates and purified as single colonies after $48-72 \mathrm{~h}$ of incubation at $30{ }^{\circ} \mathrm{C}$. Haemolytic activity of the strain was tested on tryptic soy blood agar containing $5 \%$ defibrinated sheep blood (Hy-Laboratories). The strain was maintained as viable cultures on the plates at $4{ }^{\circ} \mathrm{C}$ and stored as $20 \%(\mathrm{v} / \mathrm{v})$ glycerol suspensions at $-80{ }^{\circ} \mathrm{C}$.

Coryn- $1^{\mathrm{T}}$ cells were Gram-positive, aerobic, non-sporeforming coccobacilli approximately $0.5-0.8 \mu \mathrm{m}$ in width and $0.8-1.5 \mu \mathrm{m}$ in length (Fig. 1). The isolate was nonmotile and grew well on marine agar, LB agar and nutrient agar at $30{ }^{\circ} \mathrm{C}$, forming small colonies approximately $1 \mathrm{~mm}$ and $2.5 \mathrm{~mm}$ in diameter after 48 and $72 \mathrm{~h}$ incubation, respectively, yellowish to yellow after $72 \mathrm{~h}$, circular, convex, smooth, opaque and non-haemolytic. Strain Coryn $-1^{\mathrm{T}}$ proliferated well on liquid LB broth or LB agar at $26-37{ }^{\circ} \mathrm{C}$ (optimum $35{ }^{\circ} \mathrm{C}$ ). The strain grew about 1.5 times faster (doubling time of around $54 \mathrm{~min}$ ) at $35{ }^{\circ} \mathrm{C}$

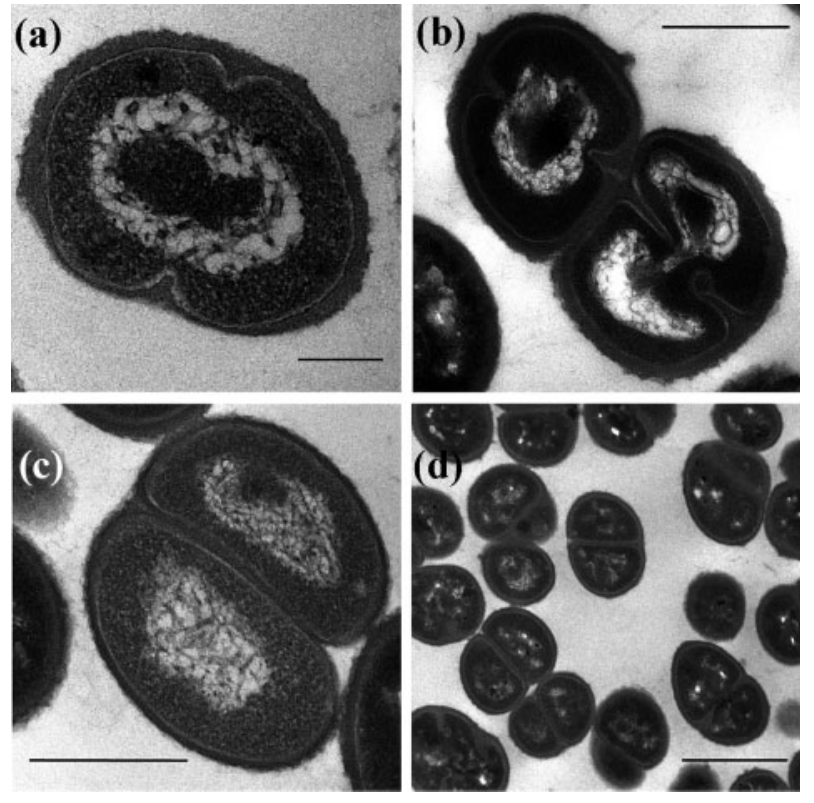

Fig. 1. Transmission electron microscopy images of cells of strain Coryn $-1^{\top}$ showing (a) ring compaction of the chromosome, as seen in initial stage of division; (b) DNA ring in different stages of segregation; (c) cells after division; (d) attached diplo cells after division. Bars, $0.2 \mu \mathrm{m}$ (a); $0.5 \mu \mathrm{m}$ (b, c); $1 \mu \mathrm{m}$ (d).

than at $26{ }^{\circ} \mathrm{C}$ (doubling time around $82 \mathrm{~min}$ ), as determined from growth curves. No growth was observed at $42{ }^{\circ} \mathrm{C}$ in liquid $\mathrm{LB}$ broth or at $45^{\circ} \mathrm{C}$ on LB agar plates. No differences in growth were detected between light and dark conditions. For $\mathrm{pH}$ tolerance experiments (on LB agar medium with $0.5 \% \mathrm{NaCl}$ ), citric acid monohydrate/ $\mathrm{Na}_{2} \mathrm{HPO}_{4}$ was used as the buffer for $\mathrm{pH}$ 5.0-7.8 and glycine $+\mathrm{NaCl} / \mathrm{NaOH}$ was used for $\mathrm{pH}$ 8.6-12.0. The isolate grew well at $\mathrm{pH}$ 7.2-9.0 (optimum $\mathrm{pH}$ 7.2). The salinity range for growth was determined both by using a sea-salt mixture (Instant Ocean) at concentrations of $0-10 \%(\mathrm{w} / \mathrm{v})$, with $0.5 \%$ sucrose as a carbon source, $0.005 \%$ yeast extract as a vitamin source and $1.5 \%$ bacteriological agar, and on LB agar plates with $\mathrm{NaCl}$ concentrations ranging between 0.5 and $25 \%(\mathrm{w} / \mathrm{v})$. Prolific growth occurred at between 0 and $10 \%$ salinity, with optimal growth being observed with $0.5-4.0 \% \mathrm{NaCl}$ or sea-salt mixture. The strain did not grow following incubation for 2 weeks at $30{ }^{\circ} \mathrm{C}$ on $\mathrm{LB}$ agar plates in an anaerobic cell (Gas Pak EZ; BD).

Strain Coryn $-1^{\mathrm{T}}$ was characterized biochemically using the API ZYM and API Coryne systems (bioMérieux), according to the manufacturer's instructions. The tests were read after 4 and $48 \mathrm{~h}$ incubation, respectively, at $37{ }^{\circ} \mathrm{C}$. The enzymic profile obtained with API ZYM strips revealed positive reactions for alkaline phosphatase, esterase (C4), esterase lipase (C8), lipase (C14), leucine arylamidase and $\alpha$-glucosidase activities. All of the other enzyme tests were deemed negative using this kit. Using the API Coryne 
system, positive results were obtained for pyrazinamidase, pyrrolidonyl arylamidase, alkaline phosphatase, $\alpha$-glucosidase and gelatin hydrolysis activities. Strain Coryn $-1^{\mathrm{T}}$ was catalase- and oxidase-positive and no fermentation of sugars was detected. Support for the distinctiveness of the novel isolate also came from its phenotypic characteristics in comparison with its closest phylogenetic relative, Corynebacterium halotolerans YIM $70093^{\mathrm{T}}$ (Table 1). A carbon-source utilization profile was obtained using the GN MicroPlate system (Biolog) in duplicate. Pure cultures (4-6 colonies) were removed from LB plates and suspended in $20 \mathrm{ml}$ sterile $0.85 \% \mathrm{NaCl}$. The suspension was then distributed into the 96-well plates, each well containing a different carbon source in each in addition to tetrazolium violet, which turns from colourless to purple in the presence of respiring cells. The plates were incubated at $30{ }^{\circ} \mathrm{C}$ for $48 \mathrm{~h}$ and changes in absorbance $\left(\mathrm{A}_{590}\right)$ were determined with an ELx808 microplate reader (BioTek Instruments). Accordingly, strain Coryn $-1^{\mathrm{T}}$ was shown to metabolize the following carbon compounds as sole energy sources: maltose, lactulose, $\beta$-hydroxybutyric acid, $\alpha$ ketovaleric acid, Tween 40, phenylethylamine, $\mathrm{N}$-acetyl-Dgalactosamine, malonic acid, L-threonine, L-glutamic acid, L-fucose, L-alanyl glycine, inosine and, less efficiently, raffinose, D-arabitol, L-asparagine and citric acid.
Antimicrobial susceptibility was tested by the agar discdiffusion method using commercial discs (Oxoid). The inhibition zone of each antibiotic was measured for the strain grown on marine agar for $48 \mathrm{~h}$ at $30{ }^{\circ} \mathrm{C}$. Strain Coryn- $1^{\mathrm{T}}$ was sensitive to sulfamethoxazole/trimethoprim, tetracycline, chloramphenicol, erythromycin, ampicillin and meticillin and was resistant to nalidixic acid.

For electron microscopy, purified cultures of the bacterium were prepared with LB broth, washed and gently mixed with $0.5 \% \mathrm{NaCl}$, fixed in Karnovsky's formaldehydeglutaraldehyde fixative (Karnovsky, 1965), treated with osmium tetroxide, dehydrated, embedded in araldite epoxy resin and sectioned into $70-80 \mathrm{~nm}$ slices. The resulting sections were stained with uranyl acetate and lead citrate and examined using a JEM-1230 transmission electron microscope (JEOL) at $80 \mathrm{kV}$ excitation. The coccobacilli of strain Coryn- $1^{\mathrm{T}}$ contained a thick peptidoglycan layer and displayed a diplo-cellular form (Fig. 1a and b) as a result of incomplete separation after cell division. The chromosomal DNA was tightly packed into a ring (Fig. $1 \mathrm{c}$ and d), and resembled that described for Deinococcus radiodurans, where such an arrangement is thought to prevent any pieces of DNA that have been broken by radiation from floating into the cytoplasm (Levin-Zaidman et al., 2003).

Table 1. Characteristics that differentiate Corynebacterium maris sp. nov. from its nearest phylogenetic relatives

Strains: 1, Corynebacterium maris sp. nov. Coryn- $1^{\mathrm{T}}$; 2, C. halotolerans YIM $70093^{\mathrm{T}}$ (data from Chen et al., 2004); 3, Corynebacterium casei LMG S-19264 ${ }^{\mathrm{T}}$ (Brennan et al., 2001); 4, Corynebacterium lipophiloflavum DSM 44291 ${ }^{\mathrm{T}}$ (Funke et al., 1997); 5, C. pilosum ATCC $29592^{\mathrm{T}}$ (Yanagawa \& Honda, 1978). All strains were positive for catalase activity. All strains were negative for $\beta$-galactosidase, $\beta$ glucosidase and $N$-acetyl- $\beta$-glucosaminidase (except $C$. pilosum, not determined) and for acid production from sucrose, mannitol, xylose and lactose. +, Positive; -, negative; ND, not determined.

\begin{tabular}{|c|c|c|c|c|c|}
\hline Characteristic & 1 & 2 & 3 & 4 & 5 \\
\hline Cell shape & Coccobacilli & $\begin{array}{l}\text { Diphtheroid and } \\
\text { irregular rods }\end{array}$ & $\begin{array}{l}\text { Irregularly } \\
\text { shaped rods }\end{array}$ & Club-shaped & Piliated rods \\
\hline Anaerobic growth & - & - & + & - & + \\
\hline Nitrate reduction & - & + & + & - & + \\
\hline \multicolumn{6}{|l|}{ Enzyme activities } \\
\hline Alkaline phosphatase & + & - & + & + & - \\
\hline Esterase & + & - & + & + & $\mathrm{ND}$ \\
\hline Esterase lipase & + & - & + & + & $\mathrm{ND}$ \\
\hline Lipase & + & + & - & + & $\mathrm{ND}$ \\
\hline Leucine arylamidase & + & - & + & + & ND \\
\hline$\beta$-Glucuronidase & - & + & - & - & ND \\
\hline$\alpha$-Glucosidase & + & - & - & - & ND \\
\hline Pyrazinamidase & + & - & + & + & ND \\
\hline Pyrrolidonyl arylamidase & + & - & + & - & ND \\
\hline Urease & - & + & - & + & + \\
\hline Oxidase & + & - & - & ND & - \\
\hline Hydrolysis of gelatin & + & + & - & ND & - \\
\hline \multicolumn{6}{|l|}{ Fermentation of: } \\
\hline Glucose & - & + & + & - & + \\
\hline Maltose & - & - & - & - & + \\
\hline Ribose & - & - & + & ND & $\mathrm{ND}$ \\
\hline DNA G $+\mathrm{C}$ content $(\mathrm{mol} \%)$ & 66.6 & 63 & 51 & 65 & 59.8 \\
\hline
\end{tabular}


Cells of Escherichia coli DH5 $\alpha$ (as control) and strain Coryn- $1^{\mathrm{T}}$ were grown for $24 \mathrm{~h}\left(37^{\circ} \mathrm{C}\right)$ and $48 \mathrm{~h}\left(30^{\circ} \mathrm{C}\right)$, respectively, to stationary phase, collected by centrifugation, washed with saline $(0.85 \%)$ and diluted to a titre of $10^{7}-10^{8}$ cells $\mathrm{ml}^{-1}$ in the same saline buffer. A suspension $(5 \mathrm{ml})$ of these cells was irradiated with $254 \mathrm{~nm}$ light from a UV lamp (UV 722; Trojan Technologies). The dose rate was measured using a UV digital radiometer (IL1400A; International Light Technologies) and shown to be $0.7 \mathrm{~mW} \mathrm{~cm}{ }^{-2}$, yielding a total dose of $7.5 \mathrm{~mJ} \mathrm{~cm}^{-2}$ in $10 \mathrm{~s}$. Comparison of the survival rates of $E$. coli and strain Coryn $-1^{\mathrm{T}}$ revealed the higher viability of strain Coryn $-1^{\mathrm{T}}$ cells under these conditions: the colony-forming ability of E. coli cells decreased by five orders of magnitude after the first $10 \mathrm{~s}$, whereas strain Coryn- $1^{\mathrm{T}}$ cells lost only $50 \%$ of viability in the same time and their viability was decreased by five orders of magnitude after $90 \mathrm{~s}$.

For the analysis of cellular fatty acids, cells of strain Coryn- $1^{\mathrm{T}}$ were grown on tryptic soy agar at $28{ }^{\circ} \mathrm{C}$. The cellular fatty acid profile was analysed using the MIDI/Hewlett Packard microbial identification system (Analytical Services), which uses GC profiles of fatty acid methyl esters. The major cellular fatty acids that were detected corresponded to oleic acid $\mathrm{C}_{18: 1} \omega 9 c(58 \%)$, palmitic acid $\mathrm{C}_{16: 0}(30 \%)$ and tuberculostearic acid 10-methyl $\mathrm{C}_{18: 0}(12 \%)$. The predominant cellular fatty acids of $C$. halotolerans (Chen et al., 2004), a species closely related to strain Coryn- $1^{\mathrm{T}}$ (94\% $16 \mathrm{~S}$ rRNA gene sequence similarity), are $\mathrm{C}_{16: 0}(42 \%), \mathrm{C}_{18: 1} \omega 9 c(29 \%)$ and 10 -methyl $\mathrm{C}_{18: 0}(7 \%)$. Mycolic acid analysis was performed by the Deutsche Sammlung von Mikroorganismen und Zellkulturen Identification Service. Mycolic acids were examined as trimethylsilylated derivatives by high-temperature GC with a microbial identification system apparatus equipped with a HT5 column (Klatte et al., 1994), which revealed the presence of short-chain mycolic acids $\left(\mathrm{C}_{30}-\mathrm{C}_{36}\right)$ in the following proportions: $\mathrm{C}_{30}(6 \%), \mathrm{C}_{32}(27 \%), \mathrm{C}_{34}(47 \%)$ and $\mathrm{C}_{36}(20 \%)$.

Genomic DNA was extracted from the bacterial cultures using a PowerSoil purification kit (Mo Bio Laboratories), according to the manufacturer's instructions. Genomic DNA was eluted with $20-40 \mu$ l elution buffer or doubledistilled water and stored at $-20{ }^{\circ} \mathrm{C}$. $16 \mathrm{~S}$ rRNA gene sequence fragments were amplified by PCR with a Mastercycler gradient thermocycler (Eppendorf) using $16 \mathrm{~S}$ rRNA primers for bacteria (forward primer, 8F, 5'-GGATCCAGACTTTGAT(C/T)(A/C)TGGCTCAG-3'; reverse primer, 1512R, 5'-GTGAAGCTTACGG(C/T)TAGCTTGTTACGACTT-3'), as described by Felske et al. (1997) with the modification that the $8 \mathrm{~F}$ primer was shortened at the $5^{\prime}$ end. The resulting $16 \mathrm{~S}$ rRNA gene sequences were compared with those in the GenBank database using the basic local alignment search tool BLAST (http://www.ncbi.nlm.nih.gov/ blast/blast.cgi) and aligned with representative corynebacterial strains using CLUSTAL $\mathrm{W}$ in the MEGA package (Kumar et al., 2004). The phylogenetic tree (Fig. 2) was constructed by the neighbour-joining method (Saitou \& Nei, 1987), using the MEGA package. Bootstrap resampling analysis (Felsenstein, 1985) with 100 replicates was performed to estimate the confidence levels of tree topologies. Sequence database searches revealed that strain Coryn- $1^{\mathrm{T}}$ was most closely related to the actinobacteria, with highest sequence similarities with species of the genus Corynebacterium (data not shown). A 16S rRNA gene sequence (1468 bases) of strain Coryn $-1^{\mathrm{T}}$ demonstrated $94 \%$ similarity to that of $C$. halotolerans YIM $70093^{\mathrm{T}}$, which was isolated from saline soil in west China (Chen et al., 2004) (Fig. 2). No sequence similarity of more than $97 \%$ was obtained with any member of the genus Corynebacterium. The genus Corynebacterium embraces a very diverse range of organisms, although phylogenetic analyses clearly demonstrate that the species form a monophyletic association (Ruimy et al., 1995). The phylogenetic tree (Fig. 2) showed that strain Coryn- $1^{\mathrm{T}}$ clustered with C. halotolerans YIM $70093^{\mathrm{T}}$ as its nearest relative into a separate subline (see also the extended phylogenetic tree, Supplementary Fig. S1, available in IJSEM Online, constructed with 67 Corynebacterium strains obtained from the Ribosomal Database Project, release 10). The clustering of strain Coryn- $1^{\mathrm{T}}$ with $C$. halotolerans YIM $70093^{\mathrm{T}}$ was supported by bootstrap resampling values of $78 \%$ (Fig. 2) and $93 \%$ (see Supplementary Fig. S1). Strain Coryn- $1^{\mathrm{T}}$, C. halotolerans YIM $70093^{\mathrm{T}}$, Corynebacterium pilosum ATCC $29592^{\mathrm{T}}$ and Corynebacterium lipophiloflavum CCUG $37336^{\mathrm{T}}$ formed a distinct, small subcluster, and maximal score sequence similarities between strain Coryn- $1^{\mathrm{T}}$ and the other three strains were 2267, 2232 and 2102, respectively, as detected by the Align two sequences (bl2seq) program (http://www.ncbi.nlm.nih.gov/staff/tao/URLAPI/ bl2seq.html). The results of the treeing analysis, together with sequence divergence values of $6 \%$ with $C$. halotolerans YIM $70093^{\mathrm{T}}$ or more with other members of the genus, therefore unequivocally demonstrated that strain Coryn- $1^{\mathrm{T}}$ represents a novel species.

For determination of the DNA G $+\mathrm{C}$ content, genomic DNA of strain Coryn- $\mathrm{T}^{\mathrm{T}}$ was prepared according to a modified version of the procedure of Wilson (1987). The $\mathrm{G}+\mathrm{C}$ content of the DNA sample was determined in three independent analyses using the HPLC technique (Mesbah et al., 1989) and was performed by the BCCM/LMG Bacteria Collection Identification Service. The DNA G +C content of strain Coryn $-1^{\mathrm{T}}$ was found to be $66.6 \mathrm{~mol} \%$.

On the basis of the phenotypic characterization and the phylogenetic analysis, strain Coryn- $1^{\mathrm{T}}$ should be classified in a novel species in the genus Corynebacterium, for which the name Corynebacterium maris sp. nov. is proposed.

\section{Description of Corynebacterium maris sp. nov.}

Corynebacterium maris (ma'ris. L. gen. n. maris of the sea).

Cells are Gram-positive, non-motile, aerobic (catalase- and oxidase-positive), non-spore-forming coccobacilli approximately $0.5-0.8 \mu \mathrm{m}$ in width and $0.8-1.5 \mu \mathrm{m}$ in length. The species is non-haemolytic and forms small colonies (approximately $1 \mathrm{~mm}$ and $2.5 \mathrm{~mm}$ in diameter after 48 


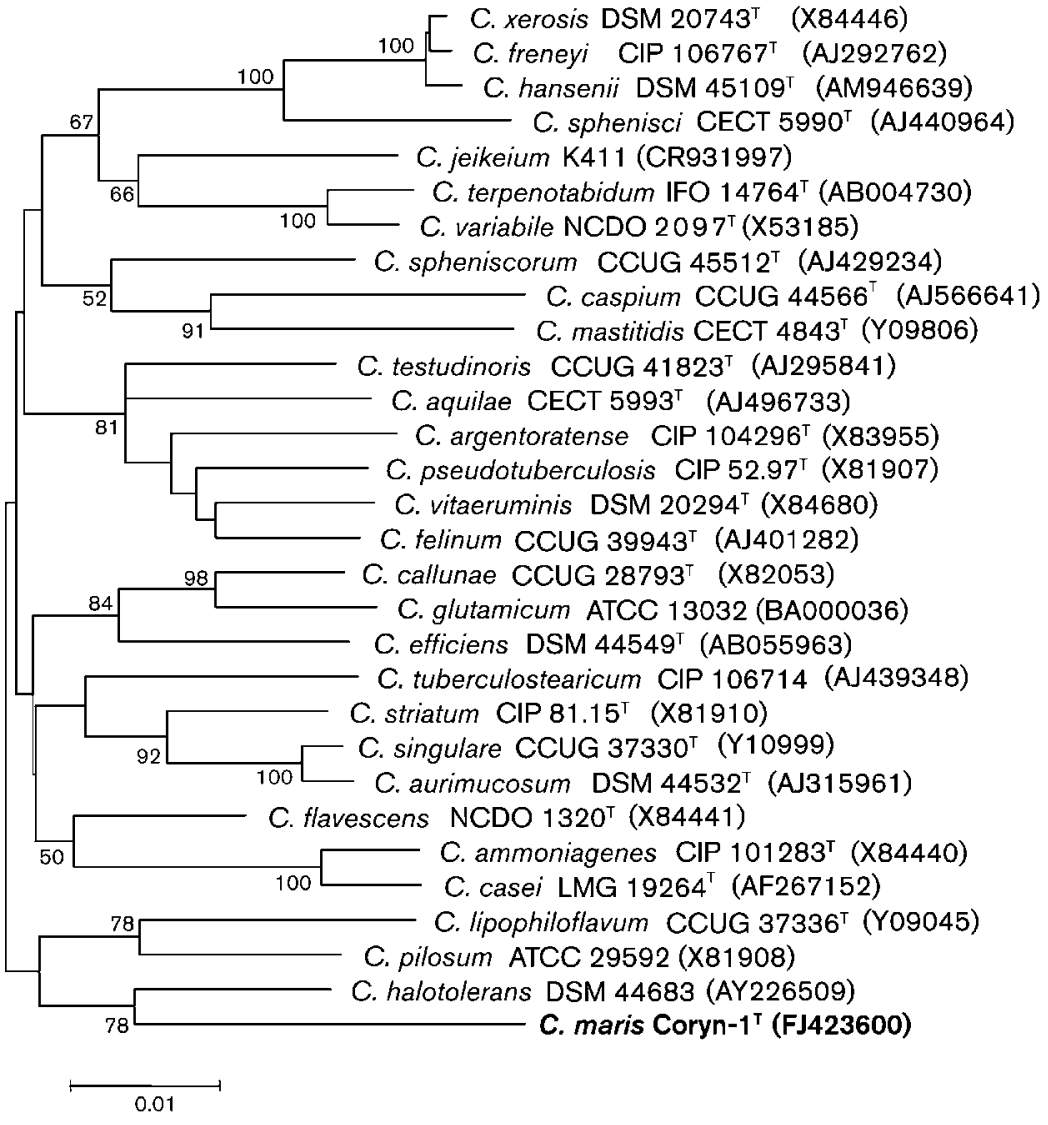

Fig. 2. Neighbour-joining $16 \mathrm{~S}$ rRNA gene sequence phylogenetic tree, based on a comparison of $\sim 1265$ bases, showing the relationship between $C$. maris $\mathrm{sp}$. nov. and 29 representative strains of the genus Corynebacterium. Bootstrap values (>50\%) based on 100 replications are shown at branch nodes. Bar, 1 substitution per 100 nucleotide positions. and $72 \mathrm{~h}$, respectively, incubation at $30{ }^{\circ} \mathrm{C}$ ) that are yellowish to yellow, circular, convex, smooth and opaque. Grows well at 0.5-4.0\% salinity, at pH 7.2-9.0 and at 30$37{ }^{\circ} \mathrm{C}$. Alkaline phosphatase, esterase (C4), esterase lipase (C8), lipase (C14), leucine arylamidase, $\alpha$-glucosidase, pyrazinamidase, pyrrolidonyl arylamidase and gelatin hydrolysis activities are detected. No activity is observed for reduction of nitrates, valine and cystine arylamidases, trypsin, $\alpha$-chymotrypsin, acid phosphatase, naphthol-ASBI phosphohydrolase, $\alpha$ - and $\beta$-galactosidases, $\beta$-glucuronidase, $\beta$-glucosidase, urease, $N$-acetyl- $\beta$-glucosaminidase, $\alpha$-mannosidase or $\alpha$-fucosidase. The strain utilizes the following carbon compounds as sole energy sources: maltose, lactulose, $\beta$-hydroxybutyric acid, $\alpha$-ketovaleric acid, Tween 40, phenylethylamine, $N$-acetyl-D-galactosamine, malonic acid, L-threonine, L-glutamic acid, Lfucose, L-alanyl glycine, inosine and, less efficiently, raffinose, D-arabitol, L-asparagine and citric acid, as determined with the Biolog GN system. Long-chain fatty acids are of the straight-chain saturated and monounsaturated types, with $\mathrm{C}_{16: 0}, \mathrm{C}_{18: 1} \omega 9 c$ and tuberculostearic acid (10-methyl $\mathrm{C}_{18: 0}$ ) predominating. Mycolic acids $\left(\mathrm{C}_{30}-\mathrm{C}_{36}\right)$ are present.

The type strain, Coryn $-1^{\mathrm{T}}\left(=\mathrm{DSM} 45190^{\mathrm{T}}=\mathrm{LMG} 24561^{\mathrm{T}}\right)$, was isolated from the mucus of the coral Fungia granulosa, Gulf of Eilat, Red Sea. The DNA G $+C$ content of the type strain is $66.6 \mathrm{~mol} \%$.

\section{Acknowledgements}

This work was supported by the National Institute for Biotechnology in the Negev (NIBN), ISF grant no. 511/02 and fellowship for D. Z. B. Y. from Council for Higher Education. We thank N. Siboni and O. Barneah for their help with sample collection and technical support and the Inter-University Institute in Eilat for the use of their facilities.

\section{References}

Barksdale, L. (1970). Corynebacterium diphtheriae and its relatives. Bacteriol Rev 34, 378-422.

Brennan, N. M., Brown, R., Goodfellow, M., Ward, A. C., Beresford, T. P., Simpson, P. J., Fox, P. F. \& Cogan, T. M. (2001). Corynebacterium mooreparkense sp. nov. and Corynebacterium casei sp. nov., isolated from the surface of a smear-ripened cheese. Int J Syst Evol Microbiol 51, 843-852.

Chen, H. H., Li, W.-J., Tang, S. K., Kroppenstedt, R. M., Stackebrandt, E., Xu, L. H. \& Jiang, C. L. (2004). Corynebacterium halotolerans sp. nov., isolated from saline soil in the west of China. Int J Syst Evol Microbiol 54, 779-782.

Collins, M. D. \& Cummins, C. S. (1986). Genus Corynebacterium Lehmann and Neumann 1896, 350 ${ }^{\mathrm{AL}}$. In Bergey's Manual of Systematic Bacteriology, vol. 2, pp. 1266-1276. Edited by P. H. A. Sneath, N. S. Mair, M. E. Sharpe \& J. G. Holt. Baltimore: Williams \& Wilkins.

Collins, M. D., Goodfellow, M. \& Minnikin, D. E. (1982). Fatty acid composition of some mycolic acid-containing coryneform bacteria. J Gen Microbiol 128, 2503-2509. 
Collins, M. D., Burton, R. A. \& Jones, D. (1988). Corynebacterium amycolatum sp. nov., a new mycolic acid-less Corynebacterium species from human skin. FEMS Microbiol Lett 49, 349-352.

Collins, M. D., Hoyles, L., Foster, G. \& Falsen, E. (2004). Corynebacterium caspium sp. nov., from a Caspian seal (Phoca caspica). Int J Syst Evol Microbiol 54, 925-928.

Euzéby, J. P. (2007). List of prokaryotic names with standing in nomenclature [cited 16 October 2008]. Available from http:// www.bacterio.cict.fr

Felsenstein, J. (1985). Confidence limits on phylogenies: an approach using the bootstrap. Evolution 39, 783-791.

Felske, A., Rheims, H., Wolterink, A., Stackebrandt, E. \& Akkermans, A. D. L. (1997). Ribosome analysis reveals prominent activity of an uncultured member of the class Actinobacteria in grassland soils. Microbiology 143, 2983-2989.

Fernández-Garayzabal, J. F., Vela, A. I., Egido, R., Hutson, R. A., Lanzarot, M. P., Fernández-Garcia, M. \& Collins, M. D. (2004). Corynebacterium ciconiae sp. nov., isolated from the trachea of black storks (Ciconia nigra). Int J Syst Evol Microbiol 54, 2191-2195.

Funke, G., Hutson, R. A., Hilleringmann, M., Heizmann, W. R. \& Collins, M. D. (1997). Corynebacterium lipophiloflavum sp. nov. isolated from a patient with bacterial vaginosis. FEMS Microbiol Lett 150, 219-224.

Giovannoni, S. J., Foster, R. A., Rappé, M. S. \& Epstein, S. (2007). New cultivation strategies bring more microbial plankton species into the laboratory. Oceanography 20, 62-69.

Goyache, J., Ballesteros, C., Vela, A. I., Collins, M. D., Briones, V., Hutson, R. A., Potti, J., García-Borboroglu, P., Domínguez, L. \& Fernández-Garayzábal, J. F. (2003). Corynebacterium sphenisci sp. nov., isolated from wild penguins. Int J Syst Evol Microbiol 53, 1009-1012.

Karnovsky, M. J. (1965). A formaldehyde-glutaraldehyde fixative of high osmolality for use in electron microscopy. J Cell Biol 27, 137A-138A.

Klatte, S., Kroppenstedt, R. M. \& Rainey, F. A. (1994). Rhodococcus opacus sp. nov., an unusual nutritionally versatile Rhodococcusspecies. Syst Appl Microbiol 17, 355-360.

Kumar, S., Tamura, K. \& Nei, M. (2004). MEGA3: integrated software for molecular evolutionary genetics analysis and sequence alignment. Brief Bioinform 5, 150-163.

Levin-Zaidman, S., Englander, J., Shimoni, E., Sharma, A. K., Minton, K. W. \& Minsky, A. (2003). Ringlike structure of the Deinococcus radiodurans genome: a key to radioresistance? Science 299, 254-256.
Mesbah, M., Premachandran, U. \& Whitman, W. B. (1989). Precise measurement of the $\mathrm{G}+\mathrm{C}$ content of deoxyribonucleic acid by highperformance liquid chromatography. Int J Syst Bacteriol 39, 159-167.

Otsuka, Y., Kawamura, Y., Koyama, T., lihara, H., Ohkusu, K. \& Ezaki, T. (2005). Corynebacterium resistens sp. nov., a new multidrugresistant coryneform bacterium isolated from human infections. J Clin Microbiol 43, 3713-3717.

Pascual, C., Lawson, P. A., Farrow, J. A., Gimenez, M. N. \& Collins, M. D. (1995). Phylogenetic analysis of the genus Corynebacterium based on $16 \mathrm{~S}$ rRNA gene sequences. Int J Syst Bacteriol 45, 724-728.

Renaud, F. N. R., Le Coustumier, A., Wilhem, N., Aubel, D., Riegel, P., Bollet, C. \& Freney, J. (2007). Corynebacterium hansenii sp. nov., an alpha-glucosidase-negative bacterium related to Corynebacterium xerosis. Int J Syst Evol Microbiol 57, 1113-1116.

Riegel, P., Creti, R., Mattei, R., Nieri, A. \& von Hunolstein, C. (2006). Isolation of Corynebacterium tuscaniae sp. nov. from blood cultures of a patient with endocarditis. J Clin Microbiol 44, 307-312.

Rosenberg, E., Koren, O., Reshef, L., Efrony, R. \& Rosenberg, I. Z. (2007). The role of microorganisms in coral health, disease and evolution. Nat Rev Microbiol 5, 355-362.

Ruimy, R., Riegel, P., Boiron, P., Monteil, H. \& Christen, R. (1995). Phylogeny of the genus Corynebacterium deduced from analyses of small-subunit ribosomal DNA sequences. Int J Syst Bacteriol 45, 740746.

Saitou, N. \& Nei, M. (1987). The neighbor-joining method: a new method for constructing phylogenetic trees. Mol Biol Evol 4, 406-425.

Ventura, M., Canchaya, C., Tauch, A., Chandra, G., Fitzgerald, G. F., Chater, K. F. \& van Sinderen, D. (2007). Genomics of Actinobacteria: tracing the evolutionary history of an ancient phylum. Microbiol Mol Biol Rev 71, 495-548.

Wilson, K. (1987). Preparation of genomic DNA from bacteria. In Current Protocols in Molecular Biology, pp. 2.4.1-2.4.5. Edited by F. M. Ausubel, R. Brent, R. E. Kingston, D. D. Moore, J. G. Seidman, J. A. Smith \& K. Struhl. New York: Green Publishing \& Wiley-Interscience.

Yanagawa, R. \& Honda, E. (1978). Corynebacterium pilosum and Coynebacterium cystitidis, two new species from cows. Int J Syst Bacteriol 28, 209-216.

Yassin, A. F., Kroppenstedt, R. M. \& Ludwig, W. (2003). Corynebacterium glaucum sp. nov. Int J Syst Evol Microbiol 53, 705709. 